\title{
Impact of External Capital on Economic Growth in EMCCA Countries
}

\author{
Thierry Mamadou Asngar ${ }^{1}$, Médard Mengue Bidzo ${ }^{2}$ \\ ${ }^{1}$ University of Djamena, Djamena, Chad \\ ${ }^{2}$ Omar Bongo University, Libreville, Gabon \\ Correspondence: Médard Mengue Bidzo, Omar Bongo University, Libreville, Gabon.
}

Received: January 31, 2019

Accepted: February 14, $2019 \quad$ Online Published: May 24, 2019

doi:10.5539/ibr.v12n6p90

URL: https://doi.org/10.5539/ibr.v12n6p90

\begin{abstract}
Taking into account the effects of financial liberalization on activity, associated with the spread of financial crises in an environment of uncertainty and dependence of the economies on external financing, updates the question of the impact of external capital on growth economic.

The purpose of this paper is to examine the impact of external capital on economic growth in developing country members of a monetary union.

Following a dynamic least squares estimation on the data of the countries of the Economic and Monetary Community of Central Africa (EMCCA), we obtain that an increase in direct investment abroad positively influences the economic growth in these countries.
\end{abstract}

Keywords: external capital, economic growth, dynamic least squares, EMCCA

\section{JEL Classifications: F31, J11, 047, 055}

\section{Introduction}

Taking into account the effects of financial liberalization on activity (Cartapanis 2010, Arellano and al, 2016), following the spread of financial crises in an environment of uncertainty and dependence of the economies on external financing (Eichengreen and al. 1999), updates the issue of the impact of external capital on economic growth.

External capital is generally presented as the set of real or financial means that enable a country to overcome its capital shortfall. Two categories are distinguished for this purpose, including financial capital (external debt, official development assistance, concessional or non-concessional financial flows, portfolio investment, etc.) and foreign direct investment (FDI) (IMF, 2016).

Economic growth is defined as the sustained increase in gross domestic product over a long period of time (Romer 1986, Aghion and ali 2010). The limitations linked to the analysis of exogenous growth to explain the origin of technical progress (Solow, 1956) have led to the analysis of its endogenous determinants, among which we distinguish between education, health and research development (Romer 1990, Lucas 1988, Barro 1997).

Much of the debate on the impact of external capital on economic growth revolves around two main lines of research related to the positive effects of external capital in the domestic country (Bekaert and Harvey, 2000), on the one hand and negative effects (Sachs, 1989), on the other hand.

On the first pillar, the analyzes lead to the idea that capital mobility allows countries with limited savings resources to attract financing for their internal investment projects. Similarly, it allows investors to diversify their portfolios, spread risk and trade inter-temporally (Eichengreen and al., 1999). In fact, the inflow of foreign capital generates diversification and better risk management because economic agents have external sources of funding in addition to internal sources (Henry, 2000). They deal with external stakeholders who face risks totally different from those borne by local stakeholders. This diversification manifests itself differently for the three capital flows retained in the context of our thesis: stock market flows, FDI and bank flows.

Regarding the second axis, two aspects related to inflows of capital are globally identified to show the negative effects of external capital on economic growth, in particular, the crowding out effect, on the one hand, and 
financial instability, on the other hand.

Indeed, capital flows can cause a drop in domestic investment (crowding out effect). They will replace domestic investment when it is oriented towards a sector where there are a large number of domestic firms; this is despite the fact that it is conceivable that such an entry by multinational firms may lead to an increase in domestic investment to cope with foreign competition (Agosin and al, 2000). The main explanation is that foreign firms outpace local firms in technology. Foreign investment will therefore "drive out" the investment of local firms and even cause bankruptcy rather than an increase in their investment.

Moreover, one of the arguments generally advanced against the entry of foreign investors into a given market is its ability to disrupt the stability of financial markets, which negatively affects economic growth (Stiglitz, 2000; Arestis and al. 2005).

This literature focuses mainly on developed countries. Indeed, very few studies to our knowledge about the relationship between economic growth and external capital are devoted to developing countries.

Revisiting seminal work, we would like to examine the relationship between economic growth and external capital in developing countries participating in a monetary union. Indeed, the low attractiveness of external capital for developing countries because of the high country risk in most of them, on the one hand and the restrictions on the freedom of capital movements imposed by the monetary union (Mundell, 1960), on the other hand, particularly motivate the analysis of the relationship between economic growth and external capital in the context of developing countries that are members of a monetary union. The aim is to identify the elements that could hinder the expected positive impact of external capital on economic activity in countries seeking economic and financial emergence.

This paper proposes to analyze the impact of external capital on economic growth, taking as a field of investigation the member countries of the Economic and Monetary Community of Central Africa (EMCCA). There are two reasons for this:

1) the member countries of the EMCCA zone are all in the process of development. They thus need a large influx of external capital to finance investments and thus to catch up with the economic and financial emergence.

2) this is an environment of great uncertainty marked by macroeconomic volatility due to external shocks with a particularly high country risk.

In this respect, we organize our study in two parts. The first part presents the model of analysis of the impact of external capital on growth (I). The second part proceeds to the empirical highlighting of this hypothesis (II).

\section{Analysis model of the impact of external capital on growth}

In this part, it is a question of specifying the model while presenting the variables, on the one hand, and to present the method of estimation.

\subsection{The Analytical Framework}

The analytical framework is based on the specified model for estimation purposes, on the one hand, and stylized facts, on the other hand.

\section{a. Specification of the model for estimation purposes}

We rely on the endogenous growth studies of Romer (1986), Barro (1997) and Aghion et ali (2010). Such a framework has the particularity of analyzing the determinants of economic growth from the angle of the New Keynesian Economy (NKE). It therefore takes into account the imperfection of markets (lack of coordination and information asymmetry) in the analysis of the factors at the root of economic growth.

The functional form of the model is as follows:

$\mathrm{GDP}=\mathrm{f}(\mathrm{kfin}, \mathrm{fdi}, \mathrm{kh}, \mathrm{kf})$

with

GDP, gross domestic product

kfin, portfolio investment flows

fdi, flows of foreign direct investment

kh, the human capital

kf, physical capital 
The model for estimation purposes takes the following form:

$$
G D P_{i t}=\beta_{0}+\beta_{1} k f_{i t}+\beta_{2} f d i_{i t}+\beta_{3} k h_{i t}+\beta_{4} k f_{i t}+\varepsilon_{i t}
$$

with,

GDPit, the country's GDP $i$ at period $t$;

kfinit, the inflow of financial capital from country i to period t;

fdiit, the ideas of country $i$ at period $t$;

khit, human capital, from country $i$ to period $t$;

kfit, the physical capital of country $i$ at period $t$;

$\varepsilon_{i t}$, the error term, independent and identically distributed.

$\beta_{1}, \beta_{2}, \beta_{3}$, and $\beta_{4}$ being the respective coefficients of portfolio investment flows (ip), foreign direct investment flows (fdi), human capital (kh) and physical capital (kf).

The model assumes that external capital impacts economic growth in the EMCCA countries.

The variable "GDP" refers to the annual growth rate of gross domestic product. GDP is the sum of gross value added generated by the productive sectors. It measures the production efforts of the economy. Its year-over-year change reflects the rate of economic growth.

The variable "kfin", that is, inflows of financial capital. Its purpose is to show the impact of foreign financial capital on the economic growth of the EMCCA countries. It presents the first variable of interest of our study. Such a variable will have as proxy the concessional financial flows.

The variable "FDI" refers to the inflow of foreign direct investment. This variable expresses all the FDI flows recorded each year in the area as a percentage of GDP. It represents the second variable of interest in our study.

The variable "kh" refers to human capital. Because of the very large content and the difficulties in expressing human capital, we prefer proxy public sector health expenditure (as a percentage of gdp) according to endogenous growth theories (Weil, 2007, Aghion and al, 2010).

Finally, for the variable "kf", we used gross fixed capital formation as a percentage of GDP. It consists of all expenditures relating to the fixed capital of the economy, net changes in inventories and acquisitions net of value. It consists of all the fixed capital expenditure of the economy.

Fixed capital consists of land development (fence, canalization, ditch, etc.), purchase of plant, equipment and machinery; and the construction of roads, rails and others such as schools, offices, hospitals, private residential housing, and commercial and industrial buildings. Inventories are inventories of goods held by firms to cope with unexpected fluctuations in production or sales and outstanding inventories.

\section{b. Analysis by the stylized fact}

The aim is to make a graphical analysis of the variables of the model, more specifically, the analysis of the relationship between economic growth and external capital (financial capital and FDI) in the four (4) countries of the sample considered.

The data used come from the World Bank database (2016) for all variables in the model. The preferred study period is 1995-2015 due to the lack of data over a broader period of the proxy variable of human capital. However, it should be noted that we consider a sample of four (4) EMCCA member countries (Cameroon, Gabon, Congo and Chad) due to the unavailability of data on concessional financial flows over the preferred period in terms of Equatorial Guinea and the Central African Republic. 
Cameroun
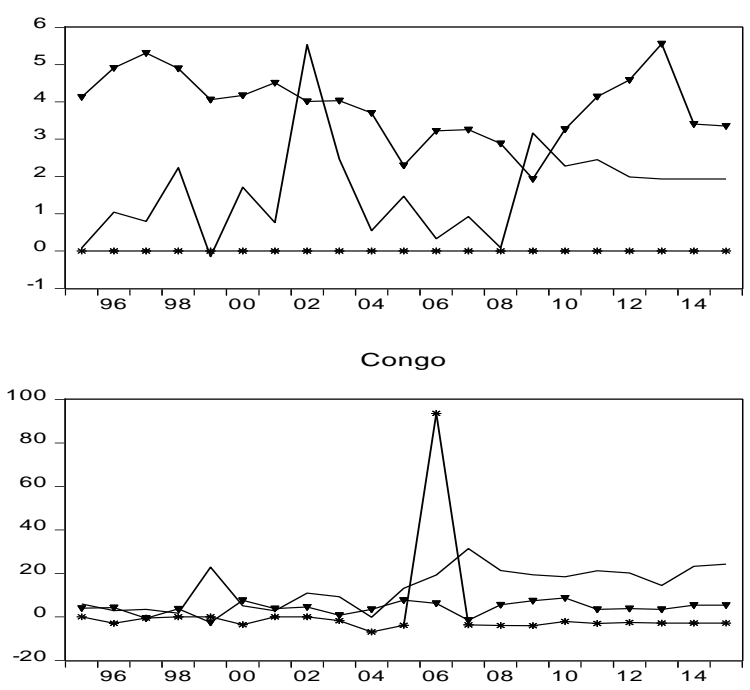

Gabon
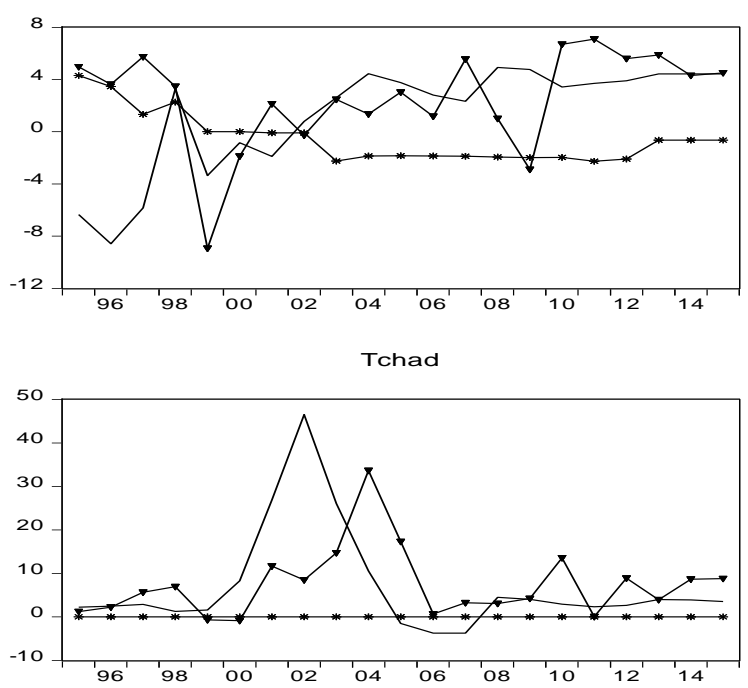

$\longrightarrow$ pib —- kfin $\longrightarrow$ ide

The analysis of the graphs shows that economic growth is moving in the same direction as foreign direct investment, which suggests a positive correlation between the two phenomena. On the other hand, we observe that financial capital is weakly correlated with economic growth in the case of Cameroon, Congo and Chad, and slightly correlated with Gabon.

Such an observation already shows us that foreign direct investment has an influence on the evolution of the growth rate of the gross domestic product in EMCCA zone unlike financial capital. This could be explained by the fact that financial integration in the area is still in an embryonic state, which makes it difficult for international transmission of financial capital to the area.

\subsection{Estimation Method}

The chosen estimator is the dynamic ordinary least squares (DOLS). It is a relevant estimator in the static panel modeling proposed by Kao and Chang (1998). Such an estimator finds its basis in the estimator of Stock and Watson (1993) for the case of time series.

Preliminary tests focus on stationarity tests to detect or not the presence of a unit root in the series of variables. Such tests avoid spurious regressions, as noted by Granger and al (1974) and Phillips (1986). The preferred test for this purpose is the Levin-Lin-Chu test, which is more suited to panel modeling (Hurlin and al, 2006).

Table 1 above presents the results from Appendix 1 of this test.

Table 1. Unit root test of Levin-Lin-Chu

\begin{tabular}{llll}
\hline & t-stat & Prob & Order of integration \\
\hline gdp & -8.878 & 0.000 & $\mathrm{I}(1)^{*}$ \\
kfin & -7.939 & 0.000 & $\mathrm{I}(1)$ \\
fdi & -7.258 & 0.000 & $\mathrm{I}(1)$ \\
kh & -7.920 & 0.000 & $\mathrm{I}(1)$ \\
kf & -8.896 & 0.000 & $\mathrm{I}(1)$ \\
\hline
\end{tabular}

* means that the variables are integrated order 1

Source: Author from the software eviews 9

The results of the stationarity tests are conclusive. Indeed, Table 1 shows that all the variables of the model are stationary in first difference.

The results obtained previously allow us to verify the existence of a long-term relationship between the variables of the model. For this, the test of Pedroni (1999) is appropriate. Thus, in the light of the results obtained, Appendix 1 shows that there is at least one cointegration relationship between the endogenous variable and the exogenous variables, thus justifying the use of the dynamic least squares technique for estimating the model.

\section{Estimation Results and Their Analysis}

We first perform the econometric estimation of our hypothesis that external capital impacts economic growth. We then proceed to the analysis of the results. 


\subsection{Results of the Overall Model Estimate}

The results of the estimation of the relationship between economic growth and external capital are given in Table 2 below.

Table 2. Estimation Results

\begin{tabular}{llll}
\hline & coefficients & t-stat & prob \\
\hline kfin & 0.021 & 0.268 & 0.792 \\
fdi & 0.230 & 3.042 & 0.008 \\
kh & 0.344 & 0.567 & 0.578 \\
kf & 0.103 & 1.390 & 0.184 \\
\hline$R^{2}=0.98$ & & & \\
\hline
\end{tabular}

Source: Author from the software eviews 9

The main statistical tests (appendix 2) support the specification of our model using the dynamic least squares method.

It also appears that only foreign direct investment flows have a significant impact on economic growth in the EMCCA countries. Indeed, a large influx of foreign capital positively and significantly impacts economic growth in EMCCA by around 23\%. On the other hand, neither portfolio investment flows, nor human capital, nor physical capital affect economic growth. Such a result should lead to a reorientation of public policies within the EMCCA zone by favoring medium and long-term capital movements in the sources of financing economic growth.

Most disturbing in the results is the low contribution of human capital to wealth creation, which suggests that the zone's learning system is inappropriate in view of the real concerns of the EMCCA economies.

\subsection{The Main Lessons}

Two main lessons emerge from the estimation results.

\section{1) The reform of the debt a means of intensifying the capital flows in zone EMCCA}

These reforms should focus primarily on the public debt policy of the countries of the zone in terms of over-indebtedness characterize them.

It is a question of putting in place a policy of reduction of the external debt of the countries of the zone, because the over-indebtedness is analogous to the situation of an insolvent company not protected by the laws of the bankruptcy. In this case, the creditors take antagonistic actions to use the remaining value of the assets, prejudicial to the survival of the company.

In such a configuration, the debt service acts as a disincentive production tax for our countries because all of its economies have reached the optimal debt threshold for which any marginal debt supplement leads to a significant reduction in debt. The investment justifying their inability to meet debt repayment commitments, and always turn to international financial institutions.

In addition, this situation leads investors to expect an increase in current and future taxes to allow the necessary transfer of resources abroad. The anticipated reduction in the after-tax return on private investment and the use of a growing share of domestic savings for debt service purposes has the effect of crowding out domestic investment and thus discouraging investment foreign.

These effects can also motivate the flight of capital, as homeowners seek to protect the value of their assets by taking advantage of more attractive investment opportunities abroad.

Reforms must consist of implementing an endogenous incentive system to attract capital by reducing the level of debt. This same idea was developed by Krugman (1988), who shows that by increasing the incentive for an over-indebted country to undertake economic reforms, creditors will be able to see the value of their claims in the secondary market improve because the debtor's repayment will have increased.

It is thus possible to say that beyond a certain level, the accumulation of external debts discourages investment and slows down growth.

\section{2) The reduction of uncertainty, a factor of attractiveness of foreign capital in situation of capital liberalization in the EMCCA}

The uncertainty concerns in particular the macroeconomic and financial instability that limits the scope of the effects of external capital in the EMCCA zone. As a result, the abundance of external flows resulting from the liberalization of the stock markets degrades the autonomy of domestic policies and forces the monetary authorities 
to maintain high interest rates to support the confidence of foreign investors. In addition, liberalization can lead to a decline in the rate of return caused by increased capital flows. This is a significant argument for the negative effect on economic growth.

The liberalization of stock markets also attracts the presence of foreign financial institutions. These institutions will compete with domestic institutions with the risk of evicting them. As for bank flows, they are also concerned by the stability problem. Foreign banks are able to reduce the credit stability of domestic banks as a whole by facilitating capital flight in times of crisis, and by increasing the risk of regional contagion as well as shocks that may occur in countries of origin foreign banks.

Indeed, foreign banks especially Western, have reduced their credit offers in EMCCA area following the financial crisis of 2008. In this case, the supply of credit does not depend on the characteristics of the economy of the host country but those of the countries of origin. Thus, the entry of foreign banks, makes the supply of credit vulnerable to both internal and external conditions (a double vulnerability). This situation is highly dependent on the uncertainty prevailing in this area.

\section{Conclusion}

This study, which analyzes the impact of external capital on economic growth, has shown that capital efficiency depends on the macroeconomic environment, including the debt ratio. Thus, in a configuration where the public debt raised the holders of capital are not encouraged to invest, so there is a negative effect on economic growth.

The results show that FDI has a significance impact, unlike other forms of capital, which suggests that it is useful to define an optimal level of public debt that makes external capital attractive.

\section{References}

Aghion, F., Howitt, P., \& Martin, F. (2010). The benefit of health: A contribution of the theories of endogenous growth. OFCE Review, 112.

Agosin, M., \& Mayer, R. (2000). Foreign Direct Investment in Developing Countries: Does it Crowd in Domestic Investment? UNCTAD Discussion Paper, 2, 146.

Arellano, M. et al. (2016). "Nonlinear Panel Data Methods for Dynamic Heterogeneous Agent Models. Annual Review of Economics.

Arestis, P., Demetriades, P. O., \& Luintel, K. B. (2001). Financial Development and Economic Growth: The Role of Stock Markets. Journal of Money, Credit and Banking, Ohio State University Press, 33(1), 16-41. https://doi.org/10.2307/2673870

Barro R. J. (1990). Government Spending in a Simple Model of Endogenous Growth. Journal of Political Economy, 98(5), S103-S125. https://doi.org/10.1086/261726

Bekaert, G., \& Harvey, C. R. (2000). Foreign Speculators and Emerging Equity Markets. Journal of Finance, 55(2), 565-613. https://doi.org/10.1111/0022-1082.00220

Cartapanis, A. (2010). "Economists and the crisis", in The Circle of Economists, What are the economists for? paris, puf-descartes.

Eichengreen, B. al. (1999). Liberalization of Capital Movements: Analytical Aspects. Economic Issues, 17, International Monetary Fund.

Granger, C. W. J., \& Newbold, P. (1974). Spurious regressions in econometrics. Journal of Econometrics, 2, 111-120. https://doi.org/10.1016/0304-4076(74)90034-7

Henry, P. B. (2000b). Do Stock Market Liberalizations Cause Investment Booms? Journal of Financial Economics, 58(1-2), 301-334. https://doi.org/10.1016/S0304-405X(00)00073-8

Hurlin, C., \& Mignon, V. (2006). A synthesis of cointegration tests on panel data, halshs-00070887.

IMF (2016). Regional Economic Outlook, Sub-Saharan Africa.

Kao, J., \& Chiang, M. (1998). On the estimation and inference of a cointegrated regression in panel data. Center for policy research. https://doi.org/10.2139/ssrn.1807931

Krugman P. (1988). Financing vs. forgiving a debt overhang. Journal of Development Economics, 29, 253-268. https://doi.org/10.1016/0304-3878(88)90044-2

Lucas, R. (1988). On the Mechanics of Economic Development. Journal of Monetary Economics, 22, 3-42. https://doi.org/10.1016/0304-3932(88)90168-7 
Mundell, R. (1960). The Monetary Dynamnics of International Adjustement under Fixed and Flexible Exchange Rates. Quarterly Journal of Economics. https://doi.org/10.2307/1884252

Pedroni, P. (1999). Critical values for cointegration tests in heterogenous panels with multiple regressors. Oxford Bulletin of Economics and Statistics, 61, 653-670. https://doi.org/10.1111/1468-0084.61.s1.14

Phillips, P. C. B. (1986). Understanding spurious regressions in econometrics. Journal of Econometrics, Elsevier, 33(3), 311-340, December. https://doi.org/10.1016/0304-4076(86)90001-1

Romer, P. (1986). Increasing Return and Long Run Growth. Journal of Political Economy, 94, October, No. 5, 1002-1037. https://doi.org/10.1086/261420

Romer, P. (1990). Endogenous Technological Change. Journal of Political Economy, 95, 71-102. https://doi.org/10.1086/261725

Sachs, J. D. (1989). Developing Country Debt and the World Economy. National Bureau of Economic Research, The University of Chicago Press. https://doi.org/10.7208/chicago/9780226733234.001.0001

Solow, R. M. (1956). A Contribution to the Theory of Economic Growth. Quarterly Journal of Economics, 70, 65-94. https://doi.org/10.2307/1884513

Stiglitz, J. E. (2000). Capital Market Liberalization, Economic Growth, and Instability. World Development, 28(6), 1075-1086. https://doi.org/10.1016/S0305-750X(00)00006-1

Stock, J., \& M, Watson (1993). A simple estimator of cointegrating vectors in higher order integrated systems. Econometrica, 61. https://doi.org/10.2307/2951763

Weil, D. (2007). Accounting for the Effect of Health on Economic Growth. The Quarterly Journal of Economics, 122(3), 126-1306. https://doi.org/10.1162/qjec.122.3.1265

World Bank. (2016). World Development Indicator. 


\section{Appendices}

Appendice 1. Pédroni cointegration test (1999)

Pedroni Residual Cointegration Test

Series: PIB KFIN FDI KH KF

Date: 10/09/18 Time: 23:16

Sample: 19952015

Included observations: 84

Cross-sections included: 4

Null Hypothesis: No cointegration

Trend assumption: No deterministic trend

User-specified lag length: 1

Newey-West automatic bandwidth selection and Bartlett kernel

Alternative hypothesis: common AR coefs. (within-dimension)

Panel v-Statistic

Panel rho-Statistic

Panel PP-Statistic

Panel ADF-Statistic

\begin{tabular}{cccc} 
Statistic & $\underline{\text { Prob. }}$ & $\begin{array}{c}\text { Weighted } \\
\text { Statistic }\end{array}$ & $\underline{\text { Prob. }}$ \\
\hline-1.934120 & 0.9735 & -2.737679 & 0.9969 \\
-0.176114 & 0.4301 & -1.603863 & 0.0544 \\
-2.854192 & 0.0022 & -4.485529 & 0.0000 \\
-1.077248 & 0.1407 & 1.342371 & 0.9103
\end{tabular}

Alternative hypothesis: individual AR coefs. (between-dimension)

Group rho-Statistic

Group PP-Statistic

Group ADF-Statistic

\begin{tabular}{cc} 
Statistic & Prob. \\
\hline-0.062336 & 0.4751 \\
-4.782062 & 0.0000 \\
-0.806172 & 0.2101
\end{tabular}

Cross section specific results

Phillips-Peron results (non-parametric)

\begin{tabular}{crrrrr} 
Cross ID & AR $(1)$ & Variance & HAC & Bandwidth & Obs \\
\hline Cameroun & 0.042 & $4.18 \mathrm{E}-28$ & $6.96 \mathrm{E}-28$ & 2.00 & 20 \\
Gabon & 0.132 & 10.17496 & 7.535176 & 6.00 & 20 \\
Congo & -0.051 & 6.908798 & 6.782645 & 1.00 & 20 \\
Tchad & -0.211 & $2.49 \mathrm{E}-28$ & $1.58 \mathrm{E}-28$ & 19.00 & 20
\end{tabular}

Augmented Dickey-Fuller results (parametric)

\begin{tabular}{ccccrr} 
Cross ID & AR(1) & Variance & Lag & Max lag & Obs \\
\hline Cameroun & 0.554 & $2.14 \mathrm{E}-28$ & 1 & -- & 19 \\
Gabon & -0.073 & 9.951431 & 1 & -- & 19 \\
Congo & -0.010 & 7.139830 & 1 & -- & 19 \\
Tchad & -0.645 & $2.26 \mathrm{E}-28$ & 1 & -- & 19 \\
\hline
\end{tabular}


Appendice 2. Overall estimation of the model

Dependent Variable: PIB

Method: Panel Dynamic Least Squares (DOLS)

Date: 10/10/18 Time: 12:05

Sample (adjusted): 19972014

Periods included: 18

Cross-sections included: 4

Total panel (balanced) observations: 72

Panel method: Weighted estimation

Cointegrating equation deterministics: $\mathrm{C}$

Fixed leads and lags specification $(\mathrm{lead}=1, \mathrm{lag}=1)$

Long-run variance weights (Bartlett kernel, Newey-West fixed bandwidth)

\begin{tabular}{|c|c|c|c|c|}
\hline Variable & Coefficient & Std. Error & t-Statistic & Prob. \\
\hline $\begin{array}{l}\text { KFIN } \\
\text { FDI } \\
\text { KH } \\
\text { KF }\end{array}$ & $\begin{array}{l}0.021049 \\
0.230818 \\
0.344608 \\
0.102710\end{array}$ & $\begin{array}{l}0.078639 \\
0.075862 \\
0.607239 \\
0.073876\end{array}$ & $\begin{array}{l}0.267664 \\
3.042621 \\
0.567499 \\
1.390311\end{array}$ & $\begin{array}{l}0.7924 \\
0.0078 \\
0.5783 \\
0.1835\end{array}$ \\
\hline $\begin{array}{l}\text { R-squared } \\
\text { Adjusted R-squared } \\
\text { S.E. of regression } \\
\text { Long-run variance }\end{array}$ & $\begin{array}{l}0.981257 \\
0.916828 \\
1.520786 \\
0.436940\end{array}$ & $\begin{array}{l}\text { Mean dependent var } \\
\text { S.D. dependent var } \\
\text { Sum squared resid }\end{array}$ & & $\begin{array}{l}4.514787 \\
5.273265 \\
37.00466\end{array}$ \\
\hline
\end{tabular}

\section{Copyrights}

Copyright for this article is retained by the author(s), with first publication rights granted to the journal.

This is an open-access article distributed under the terms and conditions of the Creative Commons Attribution license (http://creativecommons.org/licenses/by/4.0/). 